\title{
THE NIGERIAN CERTIFICATE IN EDUCATION (NCE): SCIENCE GRADUATES' EMPLOYABILITY
}

\author{
AINA JACOB KOLA*, ABDULRAHMAN ABDULGAFAR OPEYEMI \\ School of Science, College of Education (Tech.) Lafiagi, Kwara State, Nigeria \\ *Email: akoja64@gmail.com
}

Received: 14 November 2020, Revised and Accepted: 12 December 2020

\begin{abstract}
This reviewed paper focused on the Nigerian Certificate in Education (NCE) and the problem of science graduates' employability as a bane for unemployment in Nigeria. The script discussed the challenges facing the NCE graduates and attributed it to the teacher education programme's issues. Some sources of these problems are inadequate curriculum, government policy, and others. The article conceptualized Application, Creativity, and Employability (ACE) to explain the unemployment challenge among the NCE science graduate in Nigeria. An ACE framework to solve this problem was formed and highlighted some benefits of the ACE for colleges of education programme. The article discussed some implications the ACE may have on the Nigerian colleges of education science.
\end{abstract}

Keywords: Creativity skill, Employability skill, Entrepreneurial skill, Problem-solving, Science application, Science education, Unemployment.

(C) 2021 The Authors. Published by Innovare Academic Sciences Pvt Ltd. This is an open access article under the CC BY license (https://creativecommons.org/licenses/by/4.0/). DOI: https://dx.doi.org/10.22159/ijoe.2021v9i1.40609. Journal homepage: https://innovareacademics.in/journals/index.php/ijoe

\section{INTRODUCTION}

Nigerian teacher education is critical to the sustainable education development of the nation. Different teacher education institutions anchor the teacher education in Nigeria, which awards various certificates to their graduates after a stipulated period. These certificates proved that they passed prescribed exams and are certified, professional teachers. The certified teachers are specialized in different subjects, which could be Science, Social Sciences or Humanities, and Arts.

The present paper is focusing on the NCE that the College of Education awards to its graduates. The Nigerian National Policy on Education (NPE) supports the establishment of the College of Education according to the NPE revised $6^{\text {th }}$ edition (National Educational Research and Development Council, 2013). The Nigerian Commission for Colleges of Education (NCCE) is saddled with coordinating colleges of education programmes (NCCE, 2012). The academic programme cut across many subjects, of which science is one. The duration of the college of education, educational programme is three years, and the certificate awarded after passing prescribed exams is the Nigerian Certificate in Education (NCCE, 2012; Adetayo, 2016). The objective of the college of education programmes is to produce teachers who will teach at the primary school and the basic junior secondary schools (Akindutire \& Ekundayo, 2012; Oritsebemigho, 2014).

Nevertheless, research studies show that the NCE science has been facing many challenges that make the holders either underemployed or unemployed. Some of these problems are lack of adequate teaching resources, quality teachers, corruption, admission policy, and many others (Okoroma, 2009; Aiyai, 2013; Asiyai, 2015; Amini-Philips \& Ogbuagwu, 2017; Nwaokugha, \& Ezeugwu, 2017; Aina, \& Joseph, 2017). One of these challenges not often mentioned in previous studies is the problem of the employability of the science education graduates, which might be due to the teacher education challenges.

\section{Teacher education challenges in Nigeria}

Various studies show that teacher education in Nigeria has catalogues of problems that make most trained science teachers lacked the repertoire for 21 $1^{\text {st-century job }}$ requirements. Some of these challenges are discussed to give a comprehensive understanding of the theme of this paper.
To start with, the science education teacher curriculum is inadequate. It was the argument of Babatunde and Buraimoh (2018); Matthew (2018) that the teacher education curriculum in Nigeria is defective. The curriculum only prepared students for teaching. The skills to do other jobs aside from the classroom teaching are rarely mentioned in the curriculum. This could explain why most teachers are impoverished in ICT knowledge because it is not significantly included in the curriculum. Given this, Israel (2018) admitted that a lack of adequate ICT knowledge is one critical problem of teacher education in the $21^{\text {st }}$ century. It will be practically impossible for an individual to show a high level of creativity without the proper ICT knowledge (Wheeler, Waite \& Bromfield, 2002 Nikolopoulou, 2018)

Funding is critical to any successful project. previous studies indicate that inadequate funding is a significant problem of teacher education in Nigeria (Akindutire \& Ekundayo, 2012; Matthew, 2013; Clement \& Mowette, 2017; Gambo \& Fasanmi, 2019). Nigeria's annual education budget is always low compared to other countries in Africa (Ubogu \& Veronica, 2018). The consequence of this is the decline in education quality (Ubogu \& Veronica, 2018).

Lack of consistency in the Nigerian government policy is another problem (Israel, 2018) that affects teacher education. The Nigeria National Policy on Education (NPE) is not often implemented as stipulated in the revised edition. Section 5; Article 81(d) (e) of the revised NPE, according to NERDC (2013, p. 26), stipulates that tertiary education shall (d) Reduce skill shortages through the production of skilled manpower relevant to the needs of the labour market. (e) Promote and encourage scholarship, entrepreneurship, and community service. Due to government education policy's inconsistency, these have not been fully implemented in most Nigerian colleges of education

Another problem of teacher education is the lack of quality control, as observed by Israel (2018) and Okeke (2019). The quality assurance control was put in place to moderate the quality of education in Nigeria, but it is worrisome as it does not affect the Nigerian educational system. According to Okeke (2018), the quality of tertiary education in Nigeria is not a thing of joy. This might suggest the high rate of unemployment in the nation because many graduates are not employable. It could also be the reason Israel (2018) argued that the NCE holders are not competent

Given this general problem, as it affects all teachers, including science teachers, the script looks at how this impacts NCE 
teachers in Nigeria. The focus of the paper is the employability of the NCE science teacher. However, for clarity, three constructs are the article's focus, which are Application, Creativity, and Employability. It implies the Application of science education knowledge, Creativity of science education graduates, and the Employability of these graduates is the crux of this article. The three are put together as ACE (Application, Creativity, and Employability).

\section{Employability skills}

Employability is a critical construct in higher education today because it links between graduates and the labour market (Pegg, Waldock, Hendy-Isaac, and Lawton, 2012). Employability may be interpreted differently by many people; however, within higher education, it is an experience, skills, attributes, and knowledge valuable to employers (Gedye \& Chalkley, 2015). Employability is a set of skills, understanding, and attributes that make a graduate gain employment or successful in a chosen occupation (Bakar, Mohamed \& Hanafi, 2007). Pegg et al. (2012) cites Harvey that employability is getting a job and developing critical, reflective abilities to empower and enhance students. Given this background, employability is not something visible but manifests as skills. Thus, Rasul, Ismail, Ismail, Rajuddin, and Rauf (2009) opined that employability skills are part of the soft skills that any employee should possess in the industrial sector today.

In an era of the industrial revolution, it is significant that graduates of higher education should be equipped with the employability skills (Asonitou, 2015) irrespective of the field of discipline. According to Wilson, Lennox, Hughes, and Brown (2017), employability skills are critical thinking, complex problem-solving, emotional intelligence, creativity, judgment, decision-making, cognitive flexibility, people management, service orientation, and coordinating with others and negotiation. Securing a job today in a challenging economy like in Nigeria requires that fresh graduates have employability skills and hard skills (Ang, 2015).

\section{NCE science education graduates employability}

Learning science is good, but the application is the best. Previous studies show that most science learning in Nigerian schools is by memorization, and students easily forget what they learned (Bernhard, Lindwall, Engkvist, \& Zhu, 2007; Aina, 2017). This suggests the reason many science education student finds it challenging to apply their knowledge to solve problems. Application of scientific knowledge is essential: this indicates the argument of Cheng, She, and Huang (2018) that application is critical to problem-solving in science. Science education students in Nigerian colleges of education typically have two significant application choices, problem-solving (reallife problem) and teaching. Science should be taught to help students develop the skill for problem-solving (Dogu, 2008). However, the majority applied the knowledge in teaching. The implication of this is that many of these graduates are not creative. Problem-solving requires some level of creative thinking (Aldous, 2005; Hu, Xiaohui, \& Shieh, 2017).

Creativity is essential for science education to enhance students' entrepreneurial skills for job creation (Aina, Nathaniel, \& Ayodele, 2019). The reason most colleges of education science students could not do any other job aside from teaching is because of the issue of creativity (Aina, \& Abdulwasiu, 2018). There are creativity skills students should have to help their employability. Rabi and Masran (2016) submitted that creative thinking is a necessary skill in the present century; hence, fluency, originality, elaboration, and flexibility are creativity skills critical for every learner. According to Wilson et al. (2017), creativity is not a new issue in education; it has focused on higher education for decades. Creativity makes a fresh graduate marketable (Rabi \& Masran, 2016), suggesting the connection between creativity and employability.
Most works in the $21^{\text {st }}$ century require graduates equipped with specific skills and attributes aside from the right academic qualifications (Suarta, Suwintana, Sudhana \& Hariyanti, 2017). These skills are known as employability, as already discussed in this script. Creativity was considered to be one of the employability skills by Wilson et al. (2017). However, the Application, Creativity and Employability (ACE) of science education in Nigeria is weak, informing why many science graduates are teachers in Nigeria.

NCE graduates in Nigeria lack the employability skills required for the industrial sector in the 21 $1^{\text {st }}$ century (Adebayo, 2016; Aina, Nathaniel, \& Ayodele, 2019). This outcome may be attributed to their training as professional teachers. However, the state of the economy in this century requires that all science graduates have high science literacy to function moderately in any economic sector (Udompong \& Wongwanich, 2014). Therefore, being professional teachers should not preclude them from working in any other industry apart from education. The reason for not being able to work outside the classroom is significantly due to not being employable due to low science literacy. Scientific literacy should equip individuals with the power to use skills, values, and knowledge associated with science to solve problems and decision-making (Fortus, Krajcik, Dershimer, Marx, \& MamlokNaaman, 2005; Rule, 2006; Genc, 2015) in any sector. It thus implies, there is a relationship between scientific literacy and employability skills. A recent study shows that science students in a Nigerian College of Education have low scientific literacy (Aina, Abdulrahman \& Ayodele, 2020).Unfortunately, many NCE science education graduates lacked many of these skills, which suggests the reason for a high rate of unemployment among these graduates (Aina, 2017). Most Nigerian science education graduates lack the skills required to work in industries: even with their fantastic certificates because they lacked the creative abilities (Bayyat, Orabi \& Altaieb, 2016).

A science education graduate could be an employer of labour without working as a teacher or under anybody. This could be possible through ACE, as the framework shows. It only requires the shift of paradigm of instruction in science teaching. The teaching strategies that enhance creativity should be employed in schools. The teacher should teach students to apply scientific knowledge to solve problems, not to only award certificates. It implies strong scientific literacy skills by all science students are required (Aina, Abdulrahman, Ayodele, 2020). A good grade is beautiful, but that alone will not be adequate to work in industries, companies, and job creation. Labour employers do not rely on the certificate alone in the $21^{\text {st }}$ century for job placement (Audu, Kamin \& Saud, 2013).

Embracing the ACE framework would discourage stakeholders in colleges of education from concentrating only on the teaching skills. In this century, a science teacher could have a job where he/she employ others as he/she focuses on the teaching profession. This is one of the ways to reduce the unemployment rate and grow the economy. However, it could only be possible through the ACE for science education.

From figure 1, there should be no concentration on only the teaching skills, but the problem-solving skills also should be part of the pre-service teacher curriculum. The frame shows that graduates have the teaching skills, which leads them to work with the government establishment as teachers. This skill is not sufficient to work in the companies and industries. However, problem-solving skills connected with creativity and employability would enable the graduates to work in the companies, industries, and other agencies. Besides, the graduates could be entrepreneurs who have jobs they manage by themselves. These could be establishing schools, small-scale businesses, and others.

For instance, science graduates have lots of opportunities they could explore. Soap and detergent businesses are there to explore as graduates of chemistry: they could also venture into the dye and chalk production and others. Those in physics education could go into the electronics and ceramic plus others. Most of the disposable electronics materials could be recycled and turn into a viable business. These are in the 
science education curriculum, but the notion that these cohorts of students are trained to be teachers has shifted students and the teachers' attention away. The challenge here is creativity and employability skills deficiency.

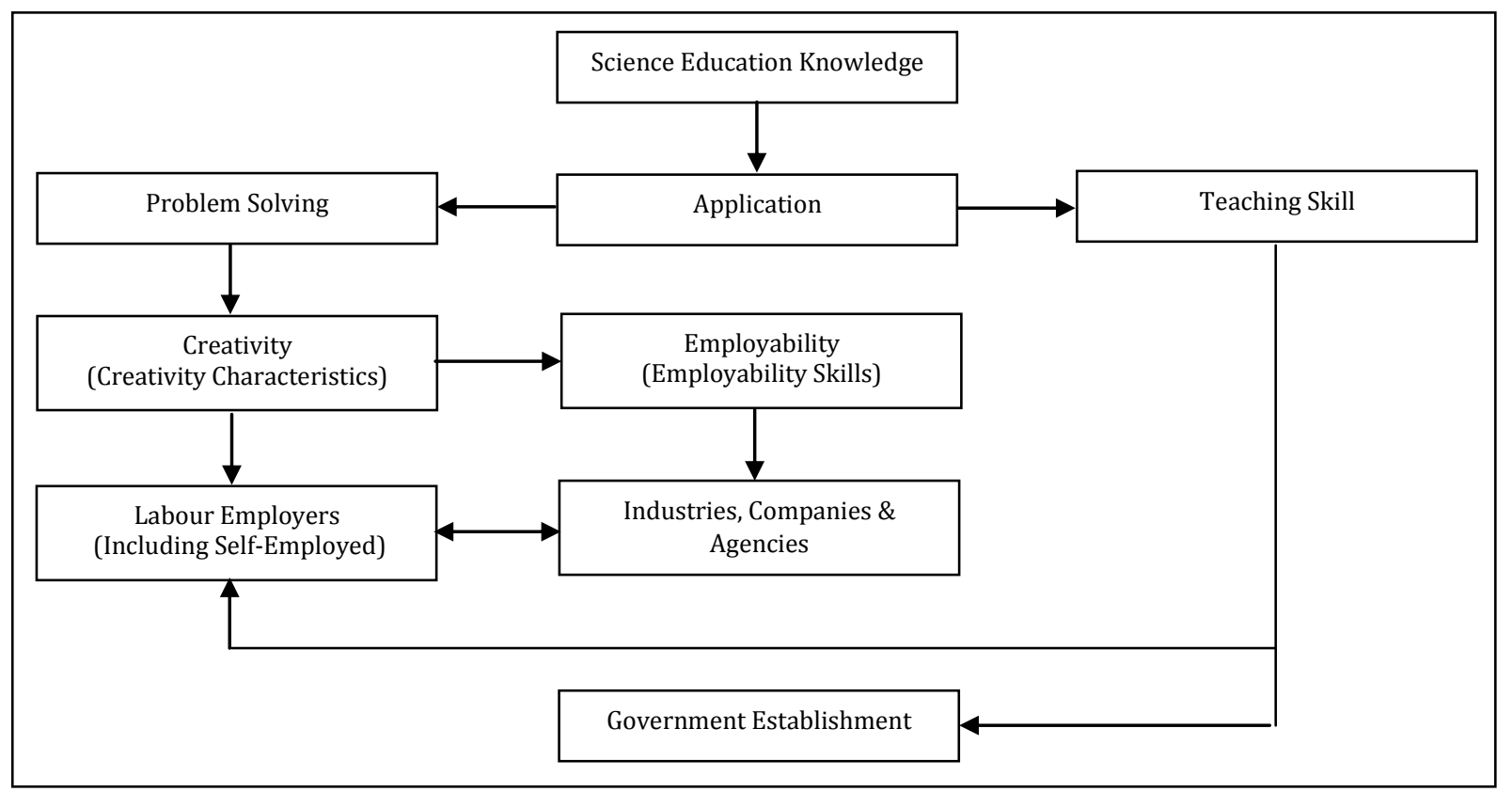

Source: Authors

Fig. 1: ACE framework for science education

\section{Benefits of ACE for science education}

The ACE framework for science education would enhance teaching and learning in science with many benefits. Some of the advantages that could be derived from the frame include enhancing job creation and opportunity; raise the Nigerian Colleges of Education standard. Besides, it could improve the Nigerian Colleges of Education science enrollment and reduce the Nation's unemployment rate.

\section{Enhancement of job creation and opportunity}

The global challenge today is that of youth unemployment Thus, most countries of the world are reforming their education to focus on employability. Restructuring the college of education science programme focusing on the ACE would ultimately help the teachers produce graduates who possessed skills for job creation. The Nigeria government alone cannot supply jobs to the college of education graduates. However, these graduates' employability skills will allow them to work in companies and industries owned by individuals and agencies. Some of these graduates could also develop entrepreneurial skills that could make them be employers of labour.

\section{Raising the standards of colleges of education}

Colleges of education in Nigeria are at the level of higher education as the university. However, because of the low-value society attached to the teaching profession, many looked down on the colleges of education. Most parents prefer polytechnic to the colleges of education because they believed anyone who graduated from a college of education would ultimately become a teacher. Therefore, only a few people support the colleges of education programmes. Most students who enroll in college do so as the last option. A significant number of students admitted to the colleges could not meet up with the university cut-off marks for admission. It is like no promising career can come out of the colleges of education except teaching. The admission policy of the colleges is not as stringent as that of the university. The government lower the admission cut-off mark and make the academic programme flexible.

Consequently, the colleges of education standard in Nigeria are not anything to reckon with like that of the university. The calibers of personnel in the college are also worrisome. Therefore, adopting the ACE frame would raise the standard of these colleges. This would enable graduates of the various colleges of education to compete with university graduates in companies, industries, and other agencies. The graduates of colleges of education would no longer only be teachers. The colleges will be admitting the best candidates; the best personnel will also be recruited to teach in these colleges.

\section{Enhance science students' enrolment}

Science student's enrolment is decreasing in the Nigerian colleges of education yearly because of many reasons. One such is the quality of graduates of these institutions. Many of the colleges of education graduates cannot do any job aside from teaching: many are not sound in the classroom. Consequently, a significant number of these graduates are jobless. Given this, parents and guardians are unwilling to enroll their wards in the college of education again. The problem of science students' enrolment in the Nigerian colleges of education was observed many years ago by a scholar (Harry, 2011). Other authors found that science enrolment in Nigerian schools is low (Aderemi, Hassan, Siyanbola \& Taiwo, 2013; Osokoya \& Junaid, 2015) due to many variables.

Science students' enrolment in the colleges of education could be enhanced through the ACE framework. As presented in figure 1 , the frame shows that the application of science education knowledge should be to both the teaching skill and problem-solving. Students will be willing to seek admission to the colleges of education once they know their careers will not be limited to teaching. Science enrolment will be boosted when physics education graduates from colleges are employed in industries, and some set up small electronics businesses. Similarly, if biology education graduates offer opportunities to work in the food processing industry, some set up a horticulture business. All these would be as a result of the creativity and employability skills acquired. 
Enhancing students' entrepreneurial skills to reduce unemployment rate

Science education is the acquisition of scientific knowledge that aids students' attitudes and science skills (Omorogbe \& Ewansiha, 2013). Hence, to reduce the high rate of unemployment in Nigeria, as observed by Omole and Ozoji (2014), science education should be quality, resulting in relevant knowledge and skills for job opportunities and creations.

The eradication of poverty and unemployment in the Nation requires the students to have entrepreneurial skills. Research studies show that entrepreneurship education is a tool to reduce the unemployment rate among youths in Nigeria (Araba, 2012) when the students are appropriately instructed. Entrepreneurial education is a global weapon employed to curb unemployment among developing countries of the world (Prabhu, 2019).

The ACE frame would empower science education graduates with the required entrepreneurship skills for job creation. The Nigeria government has introduced entrepreneurial education in colleges of education as an antidote to unemployment. However, the government efforts to introduce entrepreneur education into the colleges of education programme is yet to be successful because graduates are still finding it difficult to get jobs after graduation. With the ACE, graduates of science education would have entrepreneurship skills, which would reduce the country's unemployment rate. The youth unemployment rate in Nigeria has reached a critical level (Udeorah \& Ogana, 2014; Onuma, 2016), as shown in Table 1, which calls for everybody's concern.

Table 1: Youth unemployment rate in Nigeria 2010-2019

\begin{tabular}{|l|l|l|}
\hline S. No. & Year & $\begin{array}{l}\text { Rate } \\
(\%)\end{array}$ \\
\hline 1 & 2010 & 9.47 \\
\hline 2 & 2011 & 9.56 \\
\hline 3 & 2012 & 9.71 \\
\hline 4 & 2013 & 9.84 \\
\hline 5 & 2014 & 8.41 \\
\hline 6 & 2015 & 7.81 \\
\hline 7 & 2016 & 12.48 \\
\hline 8 & 2017 & 13.96 \\
\hline 9 & 2018 & 13.72 \\
\hline 10 & 2019 & 13.96 \\
\hline
\end{tabular}

Source: Plecher (2020).

The table shows that unemployment is increasing from 2010 to 2019 except for 2013 to 2015. Most graduates of Nigerian colleges of education are jobless, roaming the street for jobs that are not existing. Among these categories of unemployment are science education graduates. Therefore, it is one of the ACE profits to reduce the unemployment rate in the Nation. This article has some implications that must be discussed.

\section{Implications}

It was earlier reviewed that one of the problems of the NCE is that the curriculum only prepared students for the teaching profession (NCCE, 2012). Therefore, for the ACE to succeed implies its integration into the NCE curriculum. The teachers must ensure science is taught for Application to life problems, creativity, and employability. The practical application of science must dominate the curriculum along with the pedagogical knowledge. The specific content knowledge without application should be discouraged. Similarly, creativity should be taken seriously. The teacher should ensure science students develop their creativity skills in every science topic taught. Some of these skills should be included in the course outlines. Doing this should not be difficult for any science education teacher. According to Wheeler et al. (2002), it is possible to use creative thinking within several learning environments to enhance knowledge and skills. Rabi et al. (2016) argued that schools' responsibility is to instill the creative thinking repertoire to learners. This would be appropriate if it is included in the school curriculum. Besides, developing students' employability skills would be accessible once they are trained on applying science and creative thinking. Nevertheless, employability should form part of the science curriculum in the colleges of education academic programmes. This implies critical thinking, complex problemsolving, emotional intelligence, decision-making, cognitive flexibility, and others must be included in the science curriculum. Finally, it does not imply that the teaching skills should be downplayed; instead, they should maintain their present position in the curriculum as stipulated by the NPE. However, ACE should also be included.

\section{CONCLUSION}

This paper critically examined the Nigerian Certificate in Education (NCE) vis-a-vis the employability of the science graduates who hold this certificate. Research studies established that this certificate's recipients have employment challenges because of problems attributed to teacher education in the country's educational system. The paper argued that three constructs are critical to science education knowledge to reduce unemployment in the Nation, which is Application, Creativity, and Employability (ACE). The article conceptualized science education understanding in Nigeria based on the three constructs. The concept indicates that the application of science education knowledge is more of a teaching skill than the problem-solving, making the graduates mostly teachers. The idea argued that science education graduates are weak in problem-solving, which makes them lack creativity and employability skills. Research studies suggest that these skills were required to create and work in companies, industries, and agencies in the $21^{\text {st }}$ century. Therefore, the script came up with the ACE framework for science education, which the authors believed would best reduce unemployment rate among the NCE holders. The frame insisted that science students in colleges of education should not only be trained to be teachers but develop their creative thinking skills to make them employable outside the classroom. The paper discussed some benefits derived from the ACE if included in the science curriculum of colleges of education. In conclusion, to reduce unemployment among the colleges of education graduates and strengthen the NCE, the ACE framework is critical for science education. The inclusion of the ACE in the science curriculum of colleges of education would make their graduates marketable in the labour market of the $21^{\text {st }}$ century. Besides, it would make the fresh graduates' job creators and employers of labour, improving the Nigerian economy.

\section{RECOMMENDATIONS}

In light of the above conclusion, the authors recommended that the Application, Creativity and Employability (ACE) framework formed part of the Nigerian science education curriculum. It, therefore, implies that science teachers should ensure learners apply science knowledge to solve real-life problems. Besides, teachers should teach to develop students' creative thinking and employability skills. Finally, the government should not be too concern about the certificate and grades but skills for job creation.

\section{AUTHORS CONTRIBUTIONS}

Dr. Aina, J. K is the principal author who wrote the entire manuscript, while Mr. Abdulrahman offers motivation and read through the manuscript for publication.

\section{CONFLICT OF INTEREST}

We declared that there is no conflict of interest.

\section{ACKNOWLEDGMENT}

We appreciate our colleagues in academia for their motivation while writing this review paper. 


\section{REFERENCES}

- $\quad$ Aderemi, H.O., Hassan, O.M., Siyanbola, W.O., \& Taiwo, K. (2013). Trends in enrolment, graduation and staffing of science and technology education in Nigeria tertiary institutions: A gender participation perspective. Educational Research and Reviews, 8(21), 2011-2020.

- Adetayo, J. O. (2016). Teachers' factors as determinants of the professional competence of the Nigeria certificate in education (NCE) teachers. Journal of Education and Practice, 7(13), 1-11.

- Aina, J. K. (2017). The physics authentic learning experience through the peer instruction. Saarbrucken, Germany: LAP Lambert Academic Publisher.

- $\quad$ Aina, J. K., \& Joseph, P. Y. (2017). Nigerian certificate in education (NCE): An exploration of physics students' achievement. Üniversitepark Bülten, 6(2), 56-65. doi.org/ 10.22521/unibulletin.2017.62.4

- Aina, J. K., \& Azeez, A. A. (2018). The peer instruction's effectiveness as teaching pedagogy: Research reviews. Cross-Currents: An International Peer-Reviewed Journal on Humanities \& Social Sciences, 4(4), 63-68.

- $\quad$ Aina, J. K., Nathaniel, N. G., \& Ayodele, M. O. (2019). The trajectories of science education in Nigeria and its challenge to sustainable development. Cross-Currents: An International Peer-Reviewed Journal on Humanities \& Social Sciences, 5(3), 53-61.

- Aina, J. K., Abdulrahman, A. O., Ayodele, M. O. (2020). Assessment of scientific literacy skills of college of education students in Nigeria. American Journal of Social Sciences and Humanities, 5(1), 207-220. doi.org/10.20448/801.51.207.220

- Akindutire, I.O., \& Ekundayo, H.T. (2012). Teacher education in a democratic Nigeria: Challenges and the way forward. Educational Research, 3(5), 429-435.

- Aldous, C. R. (2005). Creativity in problem solving: Uncovering the origin of new ideas. International Education Journal, ERC2004 Special Issue, 5(5), 43-56.

- Amini-Philips, C., \& Ogbuagwu, C. (2017). Corruption and administration of higher education institutions in Nigeria. World Journal of Social Science, 4(2), 12-17. doi.org/ 10.5430/wjss.v4n2p12

- Ang, M. C. H. (2015). Graduate employability awareness: A gendered perspective. Procedia-Social and Behavioral Sciences, 211(2015), 192-198. doi.org/10.1016/j.sbspro.2015.11.083

- Araba, S.O. (2012). Entrepreneurial education as a tool for reducing unemployment in Nigeria. (Master thesis, Babcock University, Nigeria) Retrieved from https://www.academia.edu/2047944/Entrepreneurial_Ed ucation_as_a_tool_for_reducing_Unemployment_in_Nigeria

- Asiyai, R. I. (2013). Challenges of quality in higher education in Nigeria in the 21st century. International Journal of Educational Planning \& Administration, 3(2), 159-172.

- $\quad$ Asiyai, R. I. (2015). Improving quality higher education in Nigeria: The roles of stakeholders. International Journal of Higher Education, 4(1), 61-70. doi.org/10.5430/ijhe.v4n1p61

- Asonitou, S. (2015). Employability skills in higher education and the case of Greece. Procedia Social and Behavioral Sciences 175 (2015) 283 - 290. doi.org/10.1016/j.sbspro.2015.01.1202

- $\quad$ Audu, R., Kamin Y. B. \& Saud, M. S. B. (2013). Acquisition of employability skills in technical vocational education: Necessity for the 21st-century workforce. Australian Journal of Basic and Applied Sciences, 7(6), 9-14.

- Babatunde, M. L., \& Braimoh, D. S. (2018). The Nigerian teacher education industry: Gaps, challenges and prospects. International Journal of Arts Humanities and Social Sciences Studies, 3(1), 47-56.

- Bakar, A. R., \& Mohamed, S., \& Hanafi, I. (2007). Employability skills: Malaysian employers perspectives. The International Journal of Interdisciplinary Social Sciences, 2(1), 264-274.

- Bayyat, M., Orabi, S. M., \& Altaieb, M. H. A. (2016). Life skills acquired in relation to teaching methods used through swimming context. Asian Social Science, 12(6), 223-231. doi.org/10.5539/ass.v12n6p223

- $\quad$ Bernhard, J., Lindwall, O., Engkvist, J., \& Zhu, X. (2007). Making physics visible and learnable through interactive lecture demonstrations. Physics Teaching in Engineering Education PTEE. Retrieved from http://www.researchgate.net/publication.

- Cheng, S., She, H., \& Huang, L. (2018). The impact of problem-solving instruction on middle school students' physical science learning: Interplays of knowledge, reasoning, and problem solving. Eurasia Journal of Mathematics, Science and Technology Education, 14(3), 731-743. doi.org/10.12973/ejmste/80902

- Clement, I., \& Mowette, M. (2017). The challenges of funding primary education in a depressed economy. International Journal of Education and Evaluation, 3(7), 65-70.

- Dogu, M. (2008). The Application of problem solving method on science teacher trainees on the solution of the environmental problems. Journal of Environmental \& Science Education, 3(1), 9 - 18.

- $\quad$ Fortus, D., Krajcik, J., Dershimer, R. C., Marx, R. W., \& Mamlok-Naaman, R. (2005). Design-based science and real-world problem-solving. International Journal of Science Education, 27(7), 855-879. doi.org/10.1080/09500690500038165

- Gambo, O. O., \& Fasanmi, S. A. (2019). Funding university education in Nigeria: The challenges and way forward. Bulgarian Journal of Science and Education Policy (BJSEO), 13(1), 80-91.

- Genc, M. (2015). The effect of scientific studies on students' scientific literacy and attitude. Journal of Ondokuz Mayıs University Faculty of Education, 34(1), 141152. doi.org/10.7822/omuefd.34.1.8

- Gedye, S., \& Chalklley, B. (2015). Employability within geography, earth and environmental sciences. GEES learning and teaching guide. The higher education academy. Retrieved from https://www.academia.edu/4029324/Employability_wit hin_Geography_Earth_and_Environmental_Sciences

- Harry, I.H. (2011). Attitudes of students towards science and science education in Nigeria. (A case study in selected secondary schools in Obio/Akpor local government area of rivers state). Continental Journal of Education Research, $4(2), 33-51$.

- Hu, R., Xiaohui, S., \& Shieh, C. (2017). A study on the Application of creative problem solving teaching to statistics teaching. EURASIA Journal of Mathematics Science and Technology Education, 13(7), 3139-3149. doi.org/10.12973/eurasia.2017.00708a

- Israel, C. H. (2018). The challenges of teacher education in the 21st century Nigeria. PEOPLE: International Journal of Social Sciences, 4(1), 716-727. doi.org/10.20319/pijss.2018.41.716727

- Mathew, I. A. (2013). Provision of secondary education in Nigeria: Challenges and way forward. Journal of African Studies and Development, 5(1), 1-9. doi.org/ 10.5897/JASD11.058

- National Commission for Colleges of education. (2012). Nigeria Certificate in Education Minimum Standards for General Education. Abuja, Nigeria: Author. 
- $\quad$ Nigerian Educational Research and Development Council. (2013). Federal Republic of Nigeria National Policy on Education ( $6^{\text {th }} E d$.). Abuja, Nigeria: Author.

- Nikolopoulou, K. (2018). Creativity and ICT: Theoretical approaches and perspectives in school education. In T. A. Mikropoulos (Ed.), Research on e-Learning and ICT in Education (pp. 87-100). Switzerland: Springer.

- Nwaokugha, D. O., \& Ezeugwu, M. C. (2017). Corruption in the education industry in Nigeria: Implications for national development. European Journal of Training and Development Studies, 4(1), 1-17

- Okeke, O. J. (2019). Quality assurance in teaching and learning in tertiary institutions in Nigeria. 92-99. Retrieved from https://www.researchgate.net/publication/333651970

- Okoroma, N. S. (2006). Educational policies and problems of implementation in Nigeria. Australian Journal of Adult Learning, 46(2), 242-263.

- Omole, C. O., \& Ozoji, B. E. (2014). Science education and sustainable development in Nigeria. American Journal of

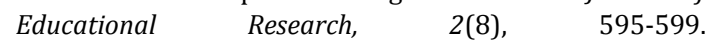
doi.org/10.12691/education-2-8-6

- Omorogbe, E., \& Ewansiha, J. (2013). The challenge of effective science teaching in Nigeria secondary schools. Academic Journal of Interdisciplinary Studies, 2(7), 181-188.

- Onuma, N. (2016). Entrepreneurship education in Nigerian tertiary institutions: A remedy to graduate unemployment. British Journal of Education, 4(5), 16-28.

- Oritsebemigho, T. 0. (2014). An appraisal of the revised Nigeria certificate in education minimum standards (English language curriculum). European Scientific Journal, Special Edition, 10, 165-171.

- Osokoya, M.M., \& Junaid, I.O. (2015). Enrolment and achievement of persons with special education needs in secondary schools in science subjects: Facts and patterns. British Journal of Education, Society \& Behavioural Science, 7(2), 137-149. doi.org/10.9734/BJESBS/2015/15039

- $\quad$ Pegg, A., Waldock, J., Hendy-Isaac, S., \& Lawton, R. (2012). Pedagogy for employability. Retrieved from https://s3.euwest-2.amazonaws.com/assets.creode.advancehe-documentmanager/documents/hea/private/pedagogy_for_employabil ity_update_2012_1568036839.pdf

- Plecher, H. (2020). Nigeria: Youth unemployment rate from 1919 to 2019. Retrieved from https://www.statista.com/statistics/812300/youthunemployment-rate-in-nigeria/
- Prabhu, J. J. (2019). A study on entrepreneurship education and entrepreneurial attitude in Malaysia-The relationship between employment and unemployment analysis. International Journal of Trend in Scientific Research and Development, 3(3), 840-842. doi.org/ 10.31142/ijtsrd23028

- Rabi, N. M., \& Masran, M. N. B. (2016). Creativity characteristics in teaching students with learning disabilities among pre-service teacher in UPSI International Journal of Advanced and Applied Sciences, 3(11), 66-72. doi.org/10.21833/ijaas.2016.11.012

- $\quad$ Rasul, M. S., Ismail, M. Y., Ismail, N., Rajuddin, M., \& Rauf, R. A. A. (2009). Importance of employability skills as perceived by employers of Malaysian manufacturing industry. Journal of Applied Sciences Research, 5(12), 2059-2066.

- Rule, A. (2006). Editorial: The components of authentic learning. Journal of Authentic Learning, 3(1), 1-10.

- $\quad$ Suarta, M., Suwintana, K., Sudhana, F. P., \& Hariyanti, K. D. (2017). Employability skills required by the 21st-century workplace: A literature review of labour market demand. Advances in Social Science, Education and Humanities Research, 102(2017), 337-342. doi.org/10.2991/ictvt17.2017.58

- $\quad$ Ubogu R. E., \& Veronica, M. O. (2018). Financing education in Nigeria: Implications and options for national development. World Journal of Educational Research, 5(3), 227-239. doi.org/10.22158/wjer.v5n3p227

- Udeorah, K.E., \& Ogana, M. (2014). Influence of entrepreneurship development on unemployment reduction in Nigeria (2009-2013). International Journal of Youth Empowerment and Entrepreneurship Development, 1(1), 82-96.

- Udompong, L., \& Wongwanich, S. (2014). Diagnosis of the scientific literacy characteristics of primary students. Procedia-Social and Behavioral Sciences, 116(2014), 50915096. doi.org/10.1016/j.sbspro.2014.01.1079

- Wheeler, S, Waite, S. J., \& Bromfield, C. (2002). Promoting creative thinking through the use of ICT. Journal of Computer Assisted Learning 18(3), 367-378. doi.org/10.1046/j.0266-4909.2002.00247.x

- Wilson, C., Lennox, P.P., Hughes, G., \& Brown, M. (2017). How to develop creative capacity for the fourth industrial revolution: creativity and employability in higher education. In F. Reisman (Ed.), Creativity, Innovation and Wellbeing (vol. V, pp. 241-274). Philadelphia, USA: KIE Conference Publications. 